AÜIFD Cilt XLIV (2003) Sayl 1 s. 513.516

\title{
“Terör Örgütlü Suç ve İnsan Hakları" Semineri (24-26 Aralık 2001, Ankara)
}

\section{Şahin GÜRSOY}

Arş Gör., Ankara Üniversitesi Sosyal Bilimler Enstitüsü

e-mail: sahingursoy69@hotmail.com

\section{Giriş}

13. Hukuk İhtisas Semineri Programı çerçevesinde uluslararası bir nitelikte düzenlenen "Terör, Örgütlü Suç ve İnsan Hakları" semineri Ankara' da düzenlendi.

İçişleri Bakanının açılış konuşmasıyla başlayan ve 3 gün süren seminerde oturum başkanlıklarını Sulhi Dönmezer yaptı ve 18 bildiri sunuldu. Her bir bildiriden sonra bildiriyle ilgili görüş ve soruların sunumu yapıldı.

\section{Tanitım}

Seminerin ilk bildirisi, Rıza Küçükoğlu' nun “Terörün Yeni Yüzü” çalışmasıydı. Seminerin hemen bütün bildirilerinde olduğu gibi bu çalışmada da 11 Eylül terör eylemleri içerik ve boyut olarak ele alındı. "AB'nin Terörle Mücadele Standartları, İngiltere'nin (Terorism Act 2000) ve ABD' nin Yeni Terörle Mücadele Kanunu (Patriot Act 2001) Feridun Yenisey tarafından ele alınarak, uluslararası terörizmle mücadelede yeni düzenlemeler yoluyla 
güvenlik birimlerine tanınan yetkilerin arttırıldığına işaret edildi. Güvenlik birimlerine tanınan yetkilerin hak ve özgürlüklerin suistimal edilmesine açık olduğu, 11 eylül sonrası, özellikle Ortadoğu kökenli müslümanlara yönelik kovuşturmalardan örnekler verilerek ifade edildi. İhsan Bal "Terörizmle Mücadele ve Proaktif Polislik" bildirisinde terör mücadelesinde kullanılan stratejileri örneklerle açıkladı. Daha sonra, M. Bedri Eryılmaz ve Vahit Bıçak, "Avrupa İnsan Hakları Mahkemesinin Terörle Mücadele Konusunda Verdiğ Kararların Analizi” ni yaptı ve Türkiye ile ilişkili kararlarla ilgili örnekler verdi. Ali Köknar (Ștratejist), "Terörle Savaş" ın zorluklarını belirtti ve stratejik tavırlar hakkında bilgi verdi. Birinci günün son bildirisinde Doğan Soyaslan, "Terörle Mücadele Kanunumuz ve Uygulamada Karşıla§̧ılan Sorunlar" hakkında bilgi verdi.

İkinci günün ilk konuşmacısı Mehmet Özcan, "Siber Terörizm ve Ulusal Güvenliği Tehdit Boyutu" isimli çalışmasıyla terörün bir başka niteliğini dile getirdi. Yine ilitişim bağlamında Önder Aytaç, "Terör Kaynaklı İletişim, Medya ve Sansür" konusunu ele aldı. Daha sonra, Sholomo Shom ve Arial Merari, "Uluslararası Terörizm" konusunu 11 Eylül olaylarıyla ilişkilendirerek ele aldılar. Akabinde Yunus Belet, "Türkiye Aleyhine Bireysel Başvurular ve AIIHM' nin Kararları" hakkında bilgi sundu. Verilen öğle arasından sonra Seminer, Sabri Uzun' un 'Türkiyenin Terörle Mücadele Pratiği" hakkındaki tebliğ̣iyle başladı. Burada özellikle bölücü ve yıkıcı terör olarak PKK ve Hizbullah terörüne karşı alınan önlemler ve elde edilen başarıdan söz etti. Daha sonra A. Selim Akyıldız, "Uluslararası Terörizm" ve Faruk Turhan, "Milosevic Davası" konularını ele aldılar.

Seminerin üçüncü gününün ilk konuşmacısı Kemal Başlar, "İnsan Hakları Kavramının Tarihi ve Felsefi Temelleri, Dünya' da ve Türkiye' de Gelişimi" hakkında bilgi sundu. Fatih Karaosmanoğlu ise "Avrupa'da Güvenlik ve İşbirliği" konusunu terör açısından değerlendirdi. İsmail Çalışkan, "Sinıraşan Örgütlü Suçlarla Mücadele ve Yolsuzluk", Metin Ekşi de "Birleşmiş Milletler Palermo Sözleşmesi (Sinıraşan Örgütlü Suçlarla Mücadele)" hakkında bilgi verdi. Daha sonra Bahri Öztürk, "Insan Hakları ve Polisin Yetkileri"ni irdeleyen bildirisini sundu. Seminer, Sulhi Dönmezer'in "Seminer Sonuç (Sentez) Raporuyla" sona erdi.

\section{Değerlendirme}

Seminerde sunulan bildirilerle ilişkili soru ve değerlendirme diyaloglarının her bir bildiriden sonra gerçekleştirilmesi dinleyicilerin de seminere aktif katılmalarına olanak sağladı. Oturum başkanlıklarını yürüten Sulhi Dönmezer' in bildiri sunumu, ara soru ve değerlendirme bölümlerinde konuşmalara zaman zaman etkin katılması seminerin dikkat çeken yönlerinden birisiydi.

Seminerde terör, örgütlü suç ve insan haklanı konuları içiçe ele alındı. Bildirilerin ortak noktalarından bir tanesi terörün, sosyal-siyasal içerikli, insanlığa karşı bir suç olduğu konusuydu. Aynı şekilde, terörün, sosyal 
düzeni yıkmak veya sarsmak, kaos ve kargaşaya yol açmak gibi amaçlar gözettiği ifade edildi. Sosyal hukuk düzeninin zafiyetinden yararlanılarak siyasal-sosyal istemlerin gerçekleştirilmesinin terörün temel hedeflerinden birisi olduğu vurgulandı.

Seminerin ilk iki günü "terör" konusu ağırlıklı bir içeriğe sahipti. Genel olarak, 11 Eylül 2001 olaylarıyla ayrı bir boyut kazanan sınır ötesi / uluslararası terör eylemleri bildirilcrin odak noktasında bulunmakla birlikte; Türkiye, Ortadoğu ve İslam dünyası sosyal, kültürel ve ekonomik yapılarıyla terör açısından özellikle değerlendirildi. Bu bağlamda, Türkiye' nin terör deneyimi de tartışıldı. Avrupa' da dar bir katılımla organize edilen terörün aksine, Türkiye' de, sosyal zeminde yaygın bir örgütlenmeyle gerçekleştirilen bölücü ve yıkıcı terörle mücadelenin zorluğuna ve önemine işaret edildi.

Her ne kadar terörün, ulus sınırlarını aşan uluslararası boyutlarından ve niteliklerinden söz edildi ise de, müslümanların üzerinde yaşadığı coğrafyanın sosyo-kültürel ve ekonomik açıdan sosyal şiddet ve teröre yol verebilecek bir karakterinin varlığına özellikle dikkat çekildi. Sosyal ve ekonomik sorunlar dolayısıyla karşılanamayan ihtiyaç ve beklentilerin gelişmişliğe ve küresel yapılanmaya karşı beslediği dışlama ve düşmanlık duygusuyla şiddete yol veren sosyal dokunun varlığına vurgu yapıldı. ABD' ye karşı gösterilen sosyal tavırlar ve ağırlıklı olarak nuüslüman kökenli birey veya gruplardan gelen şiddet eylemleri de bu çerçevede irdelendi. Burada, gelişmiş ülkelerin sömürücü tutumlarının etkisi de ifade edildi. Aynı şekilde, İslam dünyasındaki karışıklıklardan ve idarelerden de; başta $\mathrm{ABD}$ olmak üzere; Batı dünyasının sorumlu görülüyor olmasının da önemine değinildi. Teröre yol veren sosyal dokunun varlığına etki eden etmen olarak medeniyetler çatışması bağlamında olmamakla birlikte, dinselliğin yeri ve önemi vurgulandı. Şehirde, ihtiyaçları karşılanamayan bireylerin, dinsel örgütlenmeler içerisinde gereksinimlerini gidermeleri ve kimlik ve kişiliklerini buralarda tanımlamalarının sosyal şiddetle olan ilişkisi değerlendirildi.

Dünyanın, en çok sosyal ve siyasal içerikli sorun ve kargaşalarıyla yüz yüze kalan bölgelerinden biri olan İslam dünyasının sosyal, ekonomik ve psiko-sosyal yapısının iyi analiz edilmesinin önemine değinildi. İslam dünyasında, demografik yapının sağlıklı bir karaktere kavuşturulması, eğitim-ögretim seviyesinin yükseltilmesi, siyasal-sosyal doku ve organizasyonda sağlanilacak gelişmelerin terörün kontrolü üzerindeki olumlu etkileri üzerinde duruldu. Sosyal, kültürel, ekonomik ve siyasal yapıda beliren gelişme ve değişmeyle birlikte, yoğun olarak dinsel bilinçle ifade edilen sosyal, kültürel, ekonomik ve siyasal tutumların, kendi sosyal mecralarnnda anlamlandırılacağına işaret edildi.

Seminerin üçüncü gününde, ağırlıklı olarak; terör, örgüitlü suçlarla mücadele, güvenlik birimlerinin yetki ve yükümlülükleri ve bu suçlarla mücadele esnasında karşılaşılacak insan hakları sorunları ele alındı. Sosyal zeminde yer bulmuş terör ve örgütlü suçlarla mücadelenin son derece güç bir 
durum olduğu belirtildi. Ayrıca, terörle mücadele sırasında; güvenlik birimlerine tanınan geniş yetkilerin kötü kullanımlara yol verebileceği özellikle ifade edildi. Yetki kullanımıyla ilişkili olarak, güvenlik birimlerinin yetki kullanım sorununda denetimin önemi üzerinde duruldu. Burada, terörle mücadelenin, güvenlik birimlerinin dışında ve üzerinde bir karakterinin varlığı da belirtildi. 